\title{
miR-140-5p inhibits cervical cancer cell phenotypes via downregulating FEN1 to halt the cell cycle
}

\author{
YANRONG GUO ${ }^{1}$ and SHIHUA LUO ${ }^{2}$ \\ ${ }^{1}$ Department of Gynecology, Hanyang Hospital, Wuhan, Hubei 430050; ${ }^{2}$ Department of Gastroenterology, \\ The Second Affiliated Hospital of Nanchang University, Nanchang, Jiangxi 330006, P.R. China
}

Received February 4, 2020; Accepted September 1, 2020

DOI: $10.3892 / \mathrm{mmr} .2020 .11552$

\begin{abstract}
Cervical cancer (CC) is a frequently occurring cancer in women with a high mortality rate. Despite improvements to therapeutic strategies, the survival outcome for patients with $\mathrm{CC}$ remains poor. Therefore, the present study aimed to investigate the molecular mechanism underlying $\mathrm{CC}$ inhibition involving microRNA (miR)-140-5p and flap structure-specific endonuclease 1 (FEN1). Bioinformatics analysis was conducted, which identified that FEN1 was associated with $\mathrm{CC}$ cell cycle progression. Subsequently, 3'untranslated region reporter assays were performed to assess the regulatory relationship between FEN1 mRNA and miR-140-5p. Functional assays, including EdU staining assay, flow cytometry, and wound healing assays, were conducted to observe CC cell phenotypes induced by alterations to miR-140-5p and FEN1 expression levels. FEN1 expression was high and miR-140-5p expression was low in CC tissues and cell lines compared with adjacent healthy tissues and a normal cervical epithelial cell line, respectively. miR-140-5p knockdown reversed small interfering RNA-FEN1-mediated suppressive effects on CC cell phenotypes, potentially via inducing cell cycle arrest at the $G_{1}$ phase. Therefore, the present study suggested that miR-140-5p may serve as an antitumorigenesis factor in CC by targeting FEN1 mRNA.
\end{abstract}

\section{Introduction}

Cervical cancer (CC) is a malignancy that occurs in cervical cells, and causes high morbidity and mortality among females in China $(1,2)$. It was reported that $\mathrm{CC}$ resulted in $>300,000$ deaths in women, and >50,000,000 women were diagnosed with CC in 2018 (3). Despite advances in screening, diagnosis, vaccination and treatments, the survival rate for

Correspondence to: Dr Shihua Luo, Department of Gastroenterology, The Second Affiliated Hospital of Nanchang University, 1 Mingde Road, Nanchang, Jiangxi 330006, P.R. China E-mail: luoshihua29@163.com

Key words: microRNA-140-5p, flap structure-specific endonuclease 1, cervical cancer, cell cycle patients with $\mathrm{CC}$ remains $<50 \%$ (4-6). The low survival rate of $\mathrm{CC}$ may result from the complex mechanisms underlying $\mathrm{CC}$, including multistep genes, complex regulators and complicated biological processes (7-9). Therefore, exploring the key molecular mechanisms underlying $\mathrm{CC}$ is important.

Flap structure-specific endonuclease 1 (FEN1) is located on human chromosome 11q12, and participates in DNA synthesis and replication (10-14). In the early 1900s, the function of FEN1 was first identified and reported (15). During the 1900s, research focused on the functions of FEN1 at the DNA level (16). In the late 1990s, it was reported that FEN1 was downregulated during differentiation of the HL-60 cell line (a human leukemia cell line) (17). Also in the late 1900s, FEN1 was identified as a novel cell proliferation marker that could be stimulated by proliferating cell nuclear antigen (PCNA) $(18,19)$. FEN1 upregulation has been identified as crucial for the maintenance of genome stability and for the progression of various malignancies occurring in prostate, lung, breast, brain, stomach and pancreatic tissues (20-27). FEN1 is upregulated in the HeLa cell line, and FEN1 inhibitor enhances ionizing radiation sensitivity of CC in vivo and in vitro (28). Previous studies have investigated the interaction between FEN1 and microRNAs (miRNAs/miRs) in human breast and hepatocellular cancer (29-31). However, the interaction between FEN1 and miRNAs in CC is not completely understood.

miRNAs, small non-coding RNAs that contain 22 nucleotides, have been reported to serve as crucial players in gene transcription and gene editing during numerous cancer cell phenotype alterations (32-35). In 2006, miR-140-5p was first studied in mouse fibroblasts cells (3T3), which indicated that miR-140-5p targeted its downstream mRNA target, histone deacetylase 4 , therefore regulating long bone development (36). In the following decade, the regulatory function of miR-140-5p was extensively explored in different types of cancer, such as gastric cancer, hepatocellular carcinoma and esophageal cancer (37-40). Moreover, several studies reported the possible cervical cancer-suppressive role of miR-140-5p via interaction with insulin like growth factor 2 mRNA binding protein 1, ADAM metallopeptidase domain 10, origin recognition complex subunit 1 and Smad3 (41-44). However, how miR-140-5p interacts with FEN1 in CC has not been previously reported.

The aim of the present study was to explore the mechanism underlying miRNA and its downstream target genes in 
cervical cancer development. Bioinformatics analysis was performed to identify a core gene that participated in $\mathrm{CC}$ cell cycle progression. The relationship between miR-140-5p and FEN1 was explored in CC cells. Cytological experiments were conducted to assess how modulating miR-140-5p and FEN1 expression levels altered $\mathrm{CC}$ cell phenotypes, especially the cell cycle profile.

\section{Materials and methods}

Differentially expressed genes (DEGs) identification and enrichment analysis. The mRNA expression profiles of GSE63514 (24 normal and 28 cancer; PMID (45), GSE64217 (2 normal and 2 cancer; www.ncbi.nlm.nih. gov/geo/query/acc.cgi?acc=GSE64217) and GSE63678 ( 5 normal and 5 cancer) (46) were obtained from the Gene Expression Omnibus (GEO) database (www.ncbi.nlm. nih.gov/gds). DEGs with thresholds of $\left|\log _{2}(\mathrm{FC})\right|>2$ and an adjusted P-value $<0.05$ were selected and uploaded to Venny (version 2.1.0; bioinfogp.cnb.csic.es/tools/venny) for screening common DEGs. Search Tool for the Retrieval of Interacting Genes/Proteins (STRING; string-db.org/cgi/input.pl) and Metascape (metascape.org/gp/index.html\#/main/step1), two online tools used for gene annotation and gene list enrichment analysis, were used to construct the protein-protein interaction network and analyze the key biological process. The relative expression of DEGs in cervical squamous cell carcinoma was assessed using the University of Alabama Cancer Database (UALCAN; ualcan.path.uab.edu/index. html). Finally, using data from The Cancer Genome Atlas (www.cancer.gov/about-nci/organization/ccg/research/structural-genomics/tcga), The Encyclopedia of RNA Interactomes (ENCORI; version 2.0; starbase.sysu.edu.cn/panCancer. php) (47) was used to identify the key gene that was closely related to the overall survival outcome of patients with $\mathrm{CC}$.

Tissue samples and characteristics record. A total of 40 cervical carcinoma tissues and 40 adjacent healthy tissues (distance from tumor margin, $>5 \mathrm{~cm}$ ) were obtained from female patients (mean age, 45 years) that underwent resection at Hanyang Hospital and The Second Affiliated Hospital of Nanchang University between March 2015 and January 2019. Patients were diagnosed with CC by three independent pathologists. The clinical characteristics of the patients are presented in Table I.

Cell lines and cell transfection. Human Uterine Cervical Epithelial Cells (HUCECs; cat. no. BNCC353405) and five human CC cell lines (HeLa, SiHa, CaSki, SW756 and C33A) were purchased from BeNa Culture Collection. Cells were cultured at $37^{\circ} \mathrm{C}$ with $5 \% \mathrm{CO}_{2}$ according to the manufacturer's protocol: SW756 cells were cultured in Leibovitz's L-15 medium (American Type Culture Collection); SiHa and C33A cells were cultured in DMEM (Hyclone; Cytiva); and HUCEC, HeLa and CaSki cells were cultured in RPMI-1640 medium (Hyclone; Cytiva). In addition, the 293T cell line was purchased from Sigma-Aldrich (Merck KGaA) for use in the 3'untranslated region (UTR) assay. 293T cells were cultured in DMEM supplemented with $2 \mathrm{mM}$ glutamine. All media was supplemented with 10\% FBS (Gibco; Thermo Fisher Scientific, Inc.).
A small interfering (si)RNA targeted against FEN1 (si-FEN1), miR-140-5p mimic, miR-140-5p inhibitor, si-negative control (NC), miR-140-5p mimic NC and miR-140-5p inhibitor NC were designed and synthesized by Shanghai GenePharma Co., Ltd.. The sequences are presented in Table SI. At $50 \%$ confluence, HeLa and CaSki cells were transfected with $50 \mathrm{nM}$ si-FEN1, miR-140-5p mimic, miR-140-5p inhibitor or a mixture of si-NC, miR-140-5p mimic NC and miR-150-5p inhibitor NC (the NC group; Figs. S1 and S2) using Lipofectamine ${ }^{\circledR} 3000$ (Invitrogen; Thermo Fisher Scientific, Inc.). At $48 \mathrm{~h}$ post-transfection, cells were used for subsequent experiments.

Reverse transcription-quantitative PCR (RT-qPCR) and western blotting. Total RNA was extracted from tissues and cells using TRIzol ${ }^{\circledR}$ (Invitrogen; Thermo Fisher Scientific, Inc.). Total RNA $(1 \mu \mathrm{g})$ was reverse transcribed into cDNA using $4 \mu \mathrm{l}$ 5X First-Strand Buffer, $2 \mu \mathrm{l}$ 0.1 M DTT, $1 \mu \mathrm{l}$ Oligo dT Primer, $1 \mu \mathrm{l}$ dNTP Mixture, $1 \mu \mathrm{l}$ Rnase inhibitor, $1 \mu \mathrm{l}$ M-MLV reverse transcriptase (cat. no. 28025013; Thermo Fisher Scientific, Inc.) and $\mathrm{ddH}_{2} \mathrm{O}$ to a volume of $20 \mu \mathrm{l}$. The following temperature protocol was used for reverse transcription: At $37^{\circ} \mathrm{C}$ for $50 \mathrm{~min}$ followed by $70^{\circ} \mathrm{C}$ for $15 \mathrm{~min}$. Subsequently, qPCR was performed using an ABI 7300 system (Applied Biosystems; Thermo Fisher Scientific, Inc.) and the SYBR Green PCR kit (Thermo Fisher Scientific, Inc.). The following thermocycling conditions were used for qPCR: $95^{\circ} \mathrm{C}$ for $10 \mathrm{~min}$; followed by 40 cycles of $95^{\circ} \mathrm{C}$ for $15 \mathrm{sec}$ and $60^{\circ} \mathrm{C}$ for $1 \mathrm{~min}$; and $40^{\circ} \mathrm{C}$ for $1 \mathrm{~min}$. The sequences of the primers used for qPCR are presented in Table II. miRNA and mRNA expression levels quantified using the $2^{-\Delta \Delta C q}$ method (48) and normalized to the internal reference genes U6 and GAPDH, respectively.

Total protein extraction, protein sample separation and transfer to the membranes were performed as previously described (49). Protein extraction was performed using lysis-M reagent (Roche Diagnostic $\mathrm{GmbH}$ ). Protein concentration was measured by performing the BCA protein assay (Pierce; Thermo Fisher Scientific, Inc.). Proteins (30 $\mu \mathrm{g})$ were separated via $10 \%$ SDS-PAGE and transferred to nitrocellulose membranes at $0.25 \mathrm{~A}$ for $2 \mathrm{~h}$ at $4^{\circ} \mathrm{C}$ in transfer buffer $(25 \mathrm{mM}$ Tris, $200 \mathrm{mM}$ glycine, $20 \%$ methanol). After blocking in $5 \%$ non-fat milk for $3 \mathrm{~h}$ at room temperature, the membranes were incubated at $4^{\circ} \mathrm{C}$ for $8 \mathrm{~h}$ with primary antibodies targeted against: FEN1 (1:2,000; cat. no. ab109132; Abcam) and GAPDH (1:2,500; cat. no. ab9485; Abcam). Subsequently, the membranes were incubated with a horseradish peroxidase-labelled secondary antibody (1:2,500; cat. no. ab205718; Abcam) for $2 \mathrm{~h}$ at room temperature. Protein bands were visualized using ECL (Pierce; Thermo Fisher Scientific, Inc.). Protein expression levels were semi-quantified using ImageJ software (version 1.46; National Institutes of Health) with GAPDH as the loading control.

3'UTR reporter assay. TargetScan Human (version 7.2; www. targetscan.org/vert_72) was used to predict the complementary sequences between FEN1 3'UTR and miR-140-5p. The wild-type (WT) 3'UTR of FEN1 mRNA containing the binding site of miR-140-5p or the mutant (MUT) 3'UTR of FEN1 mRNA containing the mutated binding site were inserted into the psiCHECK 2 vector (Promega Corporation) 
Table I. Baseline demographics and clinical characteristics of patients with cervical cancer $(n=40)$.

\begin{tabular}{lc}
\hline Characteristic & $\mathrm{n}(\%)$ \\
\hline Age (years) & \\
$<45$ & $23(57.5)$ \\
$\geq 45$ & $17(42.5)$ \\
Histologic diagnosis & \\
Adenocarcinoma & $18(45)$ \\
Squamous carcinoma & $22(55)$ \\
Differentiation & \\
Low differentiation & $26(65)$ \\
High differentiation & $14(35)$ \\
Pathological stage & \\
I-IIa & $21(52.5)$ \\
IIb-IV & $19(47.5)$ \\
Lymph node metastasis & \\
Yes & $13(32.5)$ \\
No & $27(67.5)$ \\
Vascular invasion & \\
Yes & $16(40)$ \\
No & $24(60)$ \\
\hline
\end{tabular}

Table II. Sequences of primers used for reverse transcriptionquantitative PCR.

\begin{tabular}{ll}
\hline Gene & \multicolumn{1}{c}{ Sequence $\left(5^{\prime} \rightarrow 3^{\prime}\right)$} \\
\hline FEN1 & F: AATGGGTGGTTTGAGAGTGGC \\
& R: CTGGTCTTCAGGCTCCCTAC \\
GAPDH & F: GTCAAGGCTGAGAACGGGAA \\
& R: AAATGAGCCCCAGCCTTCTC \\
miR-140-5p & F: TGCGGCAGTGGTTTTACCCTATG \\
& R: CCAGTGCAGGGTCCGAGGT \\
U6 & F: TGCGGGTGCTCGCTTCGGCAGC \\
& R: CCAGTGCAGGGTCCGAGGT
\end{tabular}

FEN1, flap structure-specific endonuclease 1; miR, microRNA; $\mathrm{F}$, forward; $\mathrm{R}$, reverse.

to establish the reporter assay constructs. The WT 3'UTR of FEN1 mRNA was mutated to 5'-CCCGGAUA-3'. 293T cells (1x10 ${ }^{5}$ cells/well) were co-transfected with $0.1 \mathrm{mg}$ FEN1-WT or FEN1-MUT and $50 \mathrm{nM}$ miR-140-5p mimic or mimic NC using Lipofectamine 3000 . At $48 \mathrm{~h}$ post-transfection, a GloMax luminometer (Promega Corporation) and a dual-luciferase kit (GeneCopoeia, Inc.) were used to quantify luciferase activities. The activity of firefly luciferase was normalized to the corresponding Renilla luciferase activity.

EdU staining assay. Cell proliferation was assessed by performing EdU staining assay using the EdU Staining Proliferation kit (cat. no. ab219801; Abcam). HeLa and CaSki cells were seeded $\left(5 \times 10^{4}\right.$ cells/well) in 96 -well plates. At $48 \mathrm{~h}$ post-transfection, $100 \mu \mathrm{l} \mathrm{EdU}(50 \mu \mathrm{M})$ was added to each well for $2 \mathrm{~h}$ at $37^{\circ} \mathrm{C}$. Cells were fixed with $200 \mu \mathrm{l} 1 \mathrm{X}$ fixative solution containing $40 \%$ formaldehyde for $15 \mathrm{~min}$ at room temperature. Subsequently, cells were permeated with $200 \mu \mathrm{l}$ $1 \mathrm{X}$ permeabilization buffer for $20 \mathrm{~min}$ at room temperature. After washing with wash buffer, cells were incubated with $100 \mu \mathrm{l}$ reaction mix for $20 \mathrm{~min}$ at room temperature. DNA content was stained using $100 \mu 1$ Hoechst 33342 stock solution $(5 \mu \mathrm{g} / \mathrm{ml})$ for $30 \mathrm{~min}$ in the dark at room temperature. Stained cells were visualized using a fluorescence microscope (magnification, x100).

Detection of cell apoptosis and cell cycle. HeLa and CaSki cells were seeded $\left(1 \times 10^{4}\right.$ cells/well $)$ into 6 -well plates. To assess cell apoptosis, at $48 \mathrm{~h}$ post-transfection, cells were stained using the Annexin V-FITC/PI cell apoptosis detection kit (Dojindo Molecular Technologies, Inc.) according to the manufacturer's instructions in the dark. To assess the cell cycle distribution, at $48 \mathrm{~h}$ post-transfection, cells were fixed and permeabilized with cool $70 \%$ ethanol overnight at $4^{\circ} \mathrm{C}$. Cells were centrifuged at $1,000 \mathrm{xg}$ for $5 \mathrm{~min}$ at $4^{\circ} \mathrm{C}$. Subsequently, cells were incubated with $50 \mathrm{mg} / \mathrm{ml}$ PI (Sigma-Aldrich; Merck KGaA) and $25 \mathrm{mg} / \mathrm{ml}$ RNaseA for $30 \mathrm{~min}$ in the dark at $37^{\circ} \mathrm{C}$. Following staining, cells were analyzed using a FACScalibur flow cytometer (BD Biosciences) and FlowJo software (version 7.6.1; Tree Star, Inc.) to quantify cell apoptosis and cell cycle distribution.

Assessment of cell migration. The wound healing assay was performed to assess HeLa and CaSki cell migration. Briefly, transfected cells were plated into 6-well plates and cultured to $90 \%$ confluence. Cells were cultured in serum-free media for $12 \mathrm{~h}$ at $37^{\circ} \mathrm{C}$. A sterile pipette tip was used to create a linear wound in the middle of the cell monolayer in each well. Following washing with PBS, cells were cultured in fresh serum-free medium for $48 \mathrm{~h}$ at $37^{\circ} \mathrm{C}$. The wounds were observed in six randomly selected fields of view using a light microscope (magnification, $\mathrm{x} 100$ ). The migration rates were calculated by comparing the width of the wound at 0 and $48 \mathrm{~h}$.

Statistical analysis. Statistical analyses were performed using GraphPad Prism software (version 7.0; GraphPad Software, Inc.). Data are presented as the mean \pm SD of three independent experiments. ENCORI (47) was used to conduct survival analysis. Comparisons among multiple groups were analyzed using one-way ANOVA followed by Dunnett's post hoc test. Comparisons of gene expression levels between tumor tissues and adjacent healthy tissues were analyzed using the Wilcoxon matched-paired signed rank test. Comparisons between two independent groups were analyzed using the paired Student's t-test. $\mathrm{P}<0.05$ was considered to indicate a statistically significant difference.

\section{Results}

Identifying genes that are associated with CC. To select key genes, three gene expression profiles (GSE63514, GSE64217 and GSE63678) were downloaded from the GEO database. A total of 64 common DEGs were identified (Fig. 1A). 
A

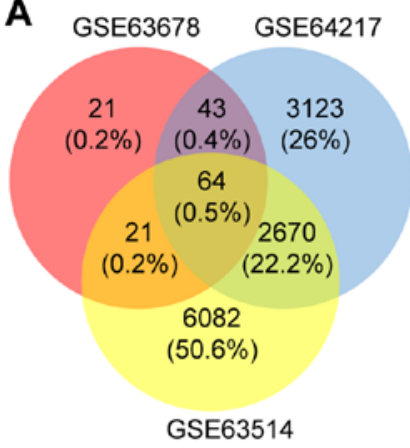

C

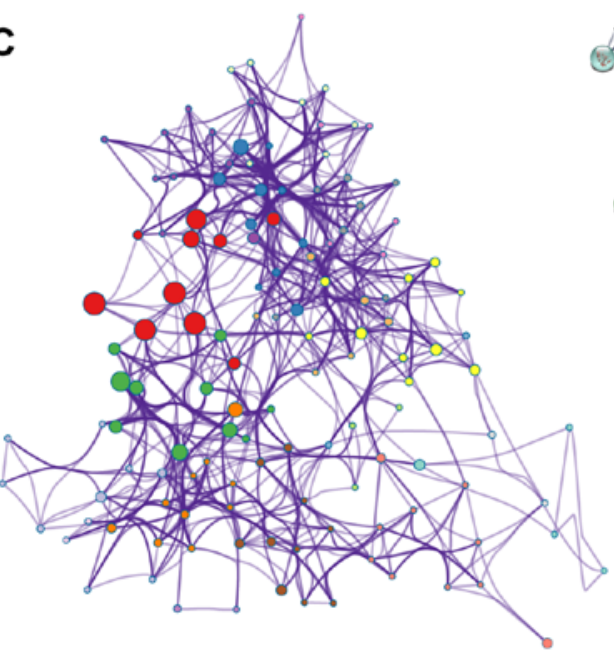

Cell cycle - Homology directed repair Regulation of cell cycle process

DNA strand elongation involved in DNA replication Cell division G1/S-Specific transcription Regulation of chromosome organization Response to antineoplastic agent

Cellular response to radiation Heart development Resolution of D-loop Structures through SDSA

- Microtubule-based process

Positivere-based process

Cellular response to hydrolase activity m Signaling by SCF-KIT

Mitotic cytokinesis Regulation of innate immune response

Signaling by Rho GTPases Chromain remodeling

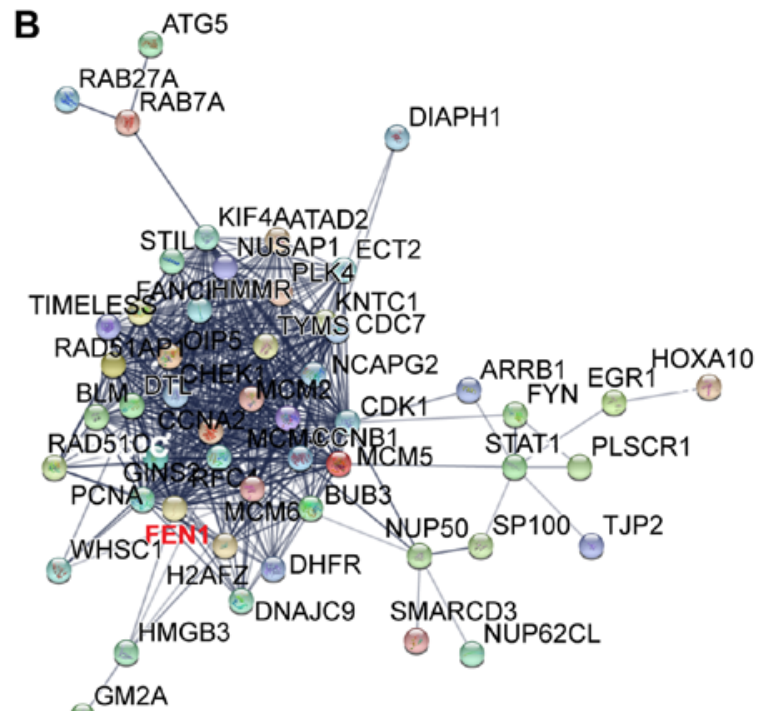

(5)
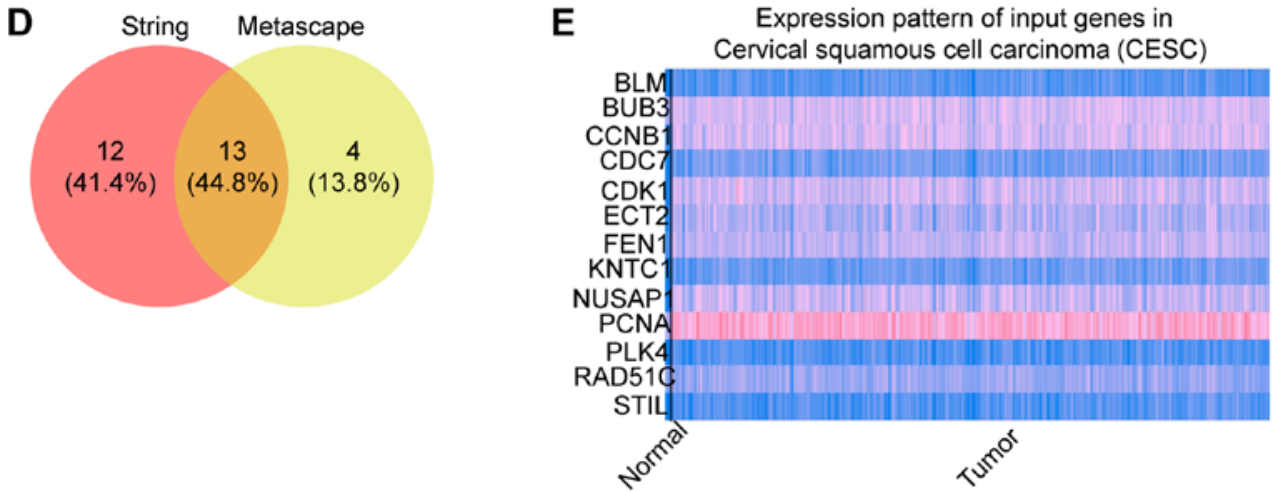

Figure 1. Identifying genes related to CC. (A) A total of 64 overlapping DEGs were selected from the GSE63514, GSE64217, GSE63678 datasets. (B) String was used to construct the protein-protein interactions network of the 64 DEGs. The cell cycle process, involving 25 genes, was identified as the key biological process. (C) The gene-gene network of candidate genes was constructed using Metascape. The cell cycle was also identified as the key biological process. (D) A total of 13 overlapping genes associated with the cell cycle were selected from the String and Metascape results. (E) The University of Alabama Cancer Database was used to construct an expression heatmap of the 13 genes CESC. Red represented upregulated genes and blue represents downregulated genes. Subsequently, six significantly upregulated genes in CESC were selected for further analysis. CC, cervical cancer; DEG, differentially expressed gene; CESC, cervical squamous cell carcinoma and endocervical adenocarcinoma; GO, Gene Ontology. 

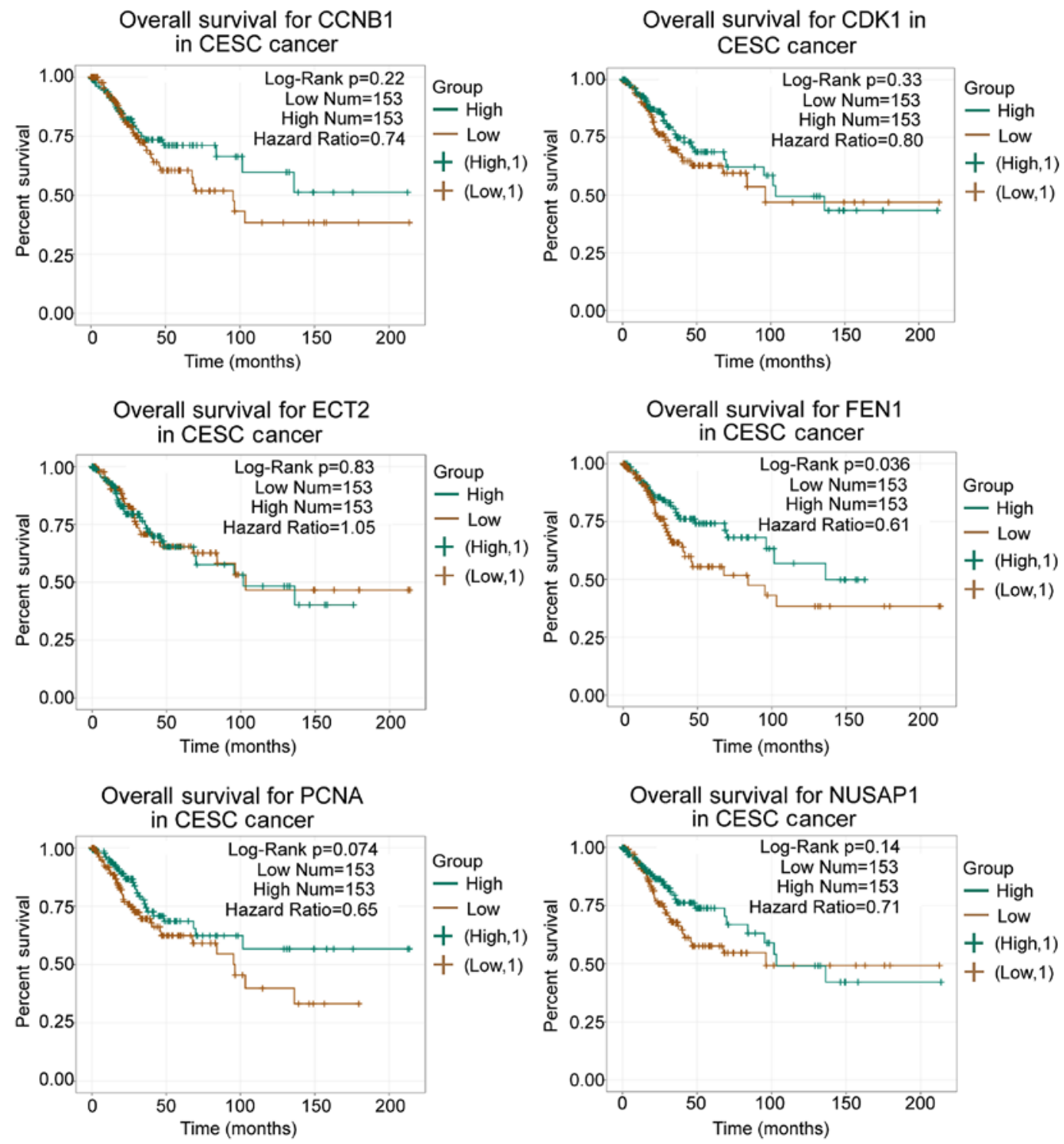

Figure 2. Prognosis analyses of the six significantly upregulated genes in patients with cervical cancer. Low FEN1 expression levels predicted an unfavorable prognosis outcome for patients. FEN1, flap structure-specific endonuclease 1; CCNB1, cyclin B1; CDK1, cyclin dependent kinase 1; ECT2, epithelial cell transforming 2; PCNA, proliferating cell nuclear antigen; NUSAP1, nucleolar and spindle associated protein 1; CESC, cervical squamous cell carcinoma and endocervical adenocarcinoma.

Subsequently, the gene interaction network was constructed using STRING and Metascape algorithms. Both algorithms indicated that the cell cycle was the key biological process including 25 genes from the STRING algorithm and 17 genes from the Metascape algorithm (Fig. 1B and C). For further analysis, 13 genes from both algorithms were selected (Fig. 1D). Among the 13 genes, cyclin B1, cyclin dependent kinase 1, epithelial cell transforming 2, FEN1, nucleolar and spindle associated protein 1 and PCNA displayed high expression levels in cervical squamous cell carcinoma compared with the healthy control, as determined via UALCAN (Fig. 1E). Subsequently, the six upregulated genes were input into ENCORI to perform prognosis analysis, which indicated that FEN1 may serve as a significant prognosis marker in patients with CC (Fig. 2). Previously, FEN1 has been reported to correlate with poor prognosis in non-small-cell lung cancer $(50,51)$ and hepatocellular carcinoma (52). Therefore, FEN1 was selected as the gene of interest in the present study to investigate its underlying mechanism in $\mathrm{CC}$.

FEN1 upregulation and miR-140-5p downregulation in CC. The results indicated that, compared with adjacent healthy tissues, FEN1 mRNA expression levels were 3.15-fold higher (Fig. 3A) and miR-140-5p expression levels were 46.6\% lower (Fig. 3B) in CC tissues. Lower miR-140-5p expression levels were associated with a poorer prognosis outcome in patients with CC, especially after 100 months, as determined via ENCORI (Fig. 3C). Consistent with the RT-qPCR results, the protein expression levels of FEN1 were 1.79-fold higher in CC tissues compared with adjacent healthy cervical tissues (Fig. 3D). FEN1 and miR-140-5p expression levels in CC cells displayed similar trends to those in $\mathrm{CC}$ tissues (Fig. 3E and F).

miR-140-5p inhibits FEN1 expression. To explore whether FEN1 was the target gene of miR-140-5p, the TargetScan 
A
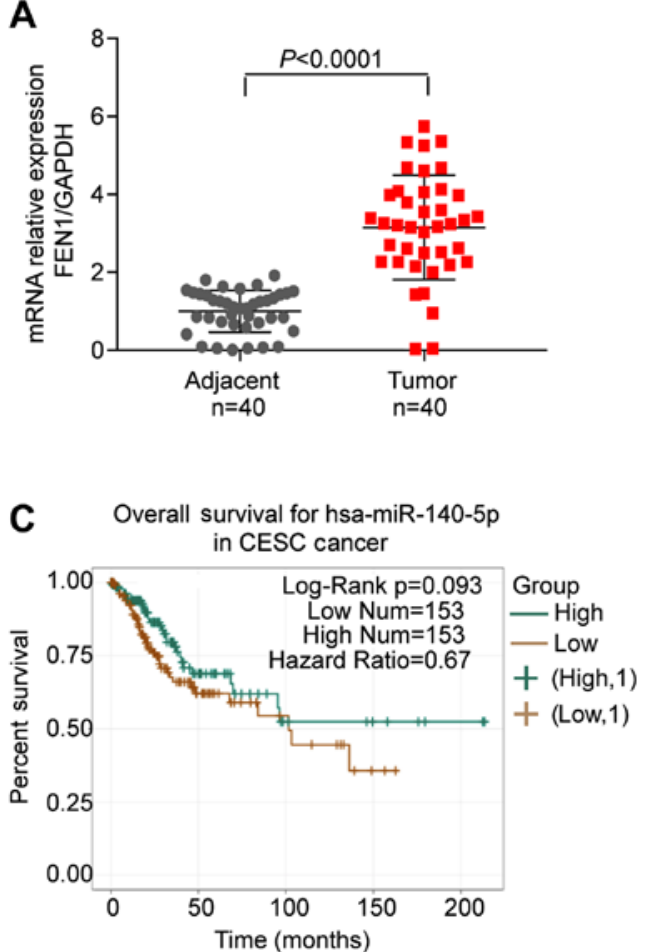
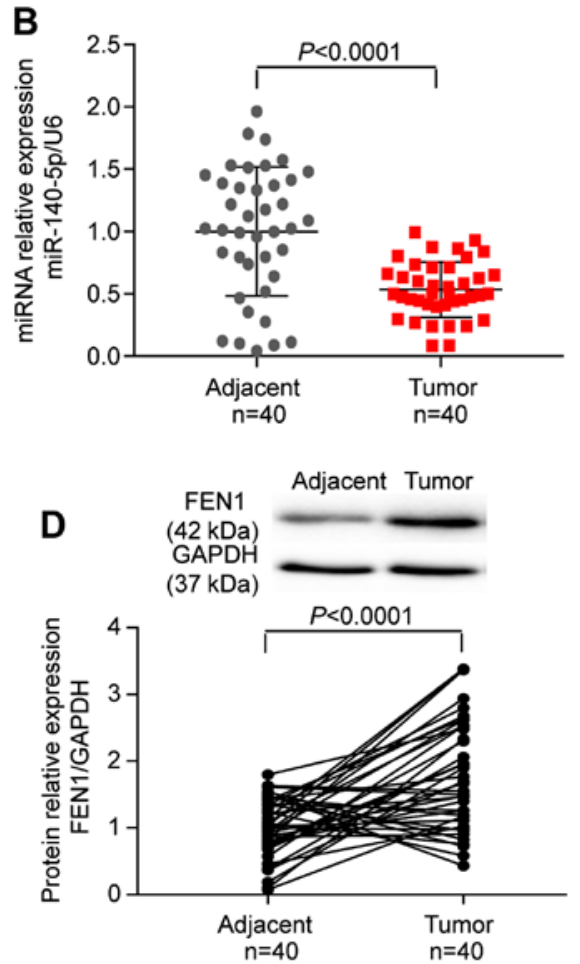

E

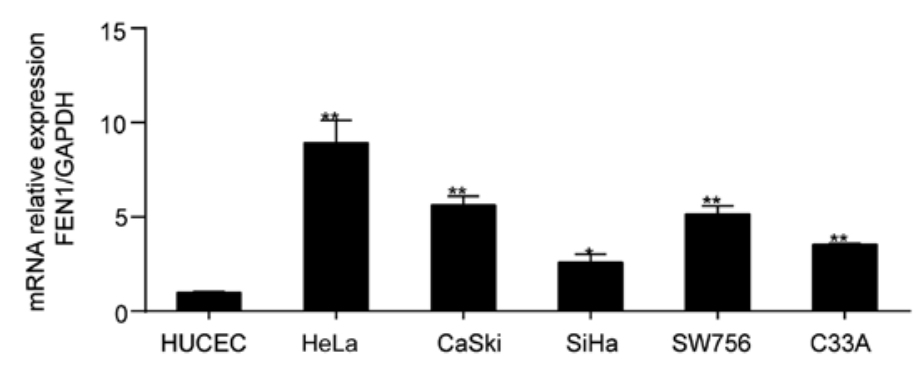

$\mathbf{F}$

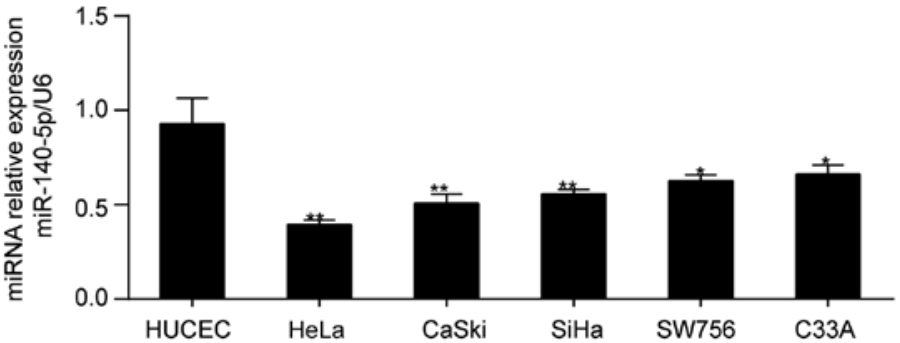

Figure 3. FEN1 is upregulated and miR-140-5p is downregulated in CC tissues and cells. (A) FEN1 and (B) miR-140-5p expression levels in CC tissues ( $\mathrm{n}=40$ ) and adjacent healthy tissues $(\mathrm{n}=40)$. (C) Low miR-140-5p expression levels were associated with poor overall survival in CESC. (D) FEN1 protein expression levels in tumor and adjacent healthy tissues. (E) FEN1 and (F) miR-140-5p expression levels in CC cell lines. "P<0.05 and ${ }^{* *} \mathrm{P}<0.001$ vs. HUCEC. FEN1, flap structure-specific endonuclease 1; miR, microRNA; CC, cervical cancer; CESC, cervical squamous cell carcinoma and endocervical adenocarcinoma.

Human algorithm was used to predict the complementary sequences between FEN1 3'UTR and miR-140-5p. The binding site was mutated using the site-directed mutation method and the mutated sequence is presented in Fig. 4A. The direct regulatory association between miR-140-5p and FEN1 mRNA 3'UTR was assessed by performing the 3'UTR reporter assay. The results indicated that luciferase activities were significantly decreased in $293 \mathrm{~T}$ cells co-transfected with miR-140-5p mimic and FEN1-WT compared with 293T cells co-transfected with mimic NC and FEN1-WT (Fig. 4B). The transfection efficiencies of miR-140-5p inhibitor and
miR-140-5p mimic were confirmed. miR-140-5p inhibitor and miR-140-5p mimic significantly decreased (by 70\%) and increased (by 2-fold) miR-140-5p expression levels, respectively, compared with the NC group (Fig. 4C). Compared with the NC group, si-FEN1 significantly decreased FEN1 expression levels by $80 \%$, miR-140-5p mimic significantly decreased FEN1 expression levels by $\sim 50 \%$ and miR-140-5p inhibitor significantly increased FEN1 expression levels by 2.5 -fold in both cell lines (Fig. 4D). Co-transfection of si-FEN1 and miR-140-5p inhibitor did not significantly alter FEN1 expression levels. 

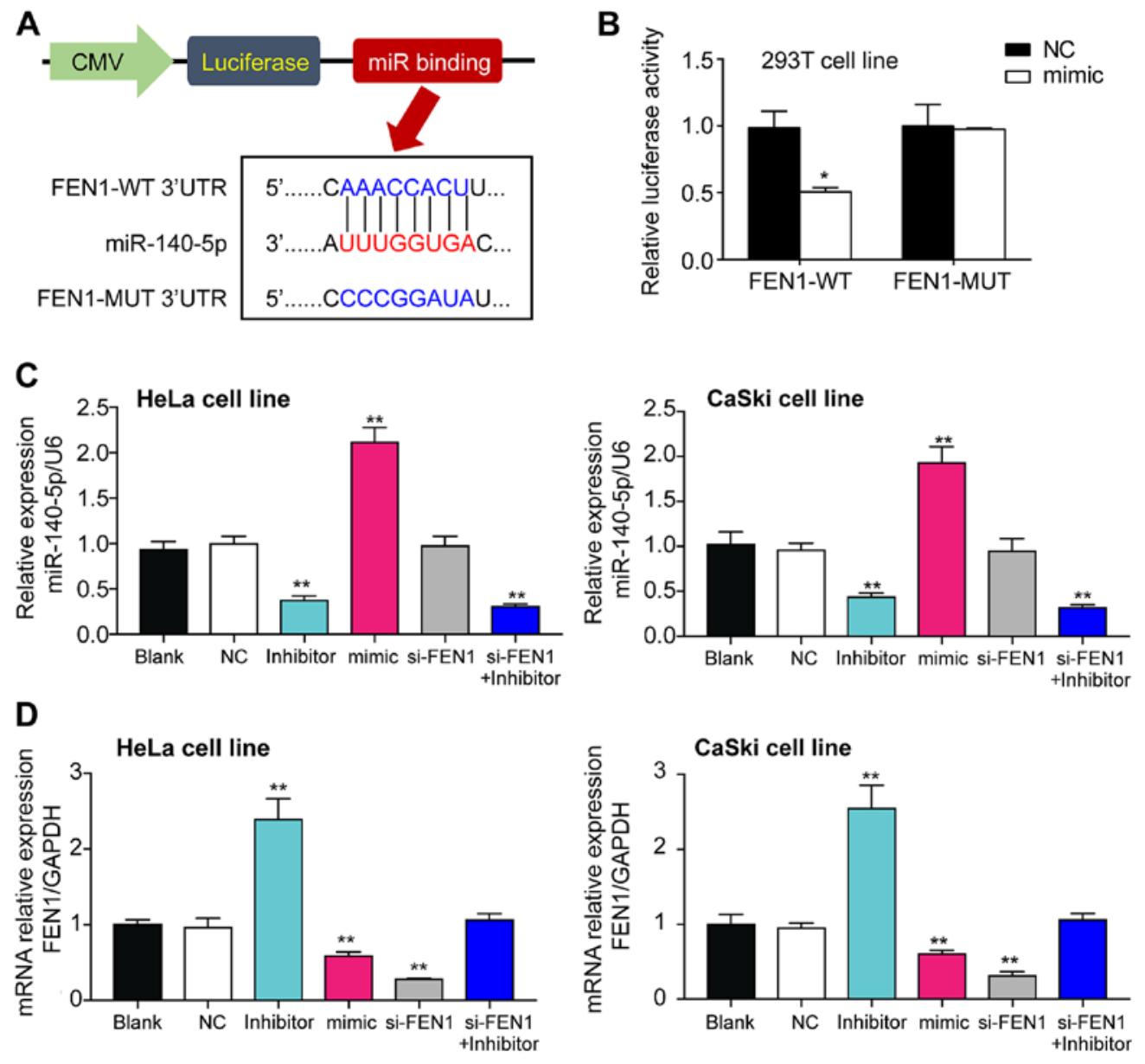

Figure 4. FEN1 is the target gene of miR-140-5p. (A) The binding site between FEN1 and miR-140-5p. (B) The dual-luciferase reporter assay indicated that miR-140-5p bound to the 3'UTR of FEN1 mRNA. "P<0.05 vs. NC. (C) miR-140-5p and (D) FEN1 expression levels in HeLa and CaSki cells transfected with NC, miR-140-5p inhibitor, miR-140-5p mimic, si-FEN1 or si-FEN1 and miR-140-5p inhibitor. ${ }^{* *} \mathrm{P}<0.001$ vs. NC. FEN1, flap structure-specific endonuclease 1; miR, microRNA; UTR, untranslated region; NC, negative control; si, small interfering RNA; CMV, cytomegalovirus promoter.

Suppressive effects of miR-140-5p on CC cell phenotypes via targeting FEN1. To further explore the mechanism underlying miR-140-5p in CC, HeLa and CaSki cells were transfected with miR-140-5p inhibitor, miR-140-5p mimic or si-FEN1. Cell proliferation was impaired by transfection with si-FEN1 or miR-140-5p mimic, but enhanced by transfection with miR-140-5p inhibitor compared with blank group. Interestingly, si-FEN1 and miR-140-5p inhibitor co-transfection did not significantly alter cell proliferation compared with the blank group (Fig. 5A). Compared with the blank group, si-FEN1 and miR-140-5p mimic significantly elevated the rate of cell apoptosis by $\sim 1.5$-fold, whereas miR-140-5p inhibitor significantly decreased the rate of cell apoptosis by $\sim 80 \%$ in HeLa cells. The rate of cell apoptosis in the co-transfection group was similar to the blank group (Fig. 5C and E). Similarly, in CaSki cells, si-FEN1 and miR-140-5p mimic significantly increased the rate of cell apoptosis by 74 and $54 \%$, respectively, whereas miR-140-5p inhibitor significantly decreased cell apoptosis by $58 \%$ compared with the blank group (Fig. $6 \mathrm{C}$ and E). The cell cycle profiling results indicated that si-FEN1 and miR-140-5p mimic significantly induced cell cycle arrest at the $G_{1}$ phase, whereas miR-140-5p inhibitor significantly decreased cell cycle arrest at the $G_{1}$ phase in both cell lines compared with the blank group (Figs. 5B, D, 6B and D). To investigate $\mathrm{CC}$ cell migration, the wound healing assay was performed. The results suggested that HeLa cell migration in the miR-140-5p inhibitor group was significantly increased by 1.5 -fold at $48 \mathrm{~h}$, whereas cell migration in the si-FEN1 and miR-140-5p mimic groups was significantly decreased by 50 and $40 \%$ at $48 \mathrm{~h}$, respectively, compared with the blank group (Fig. 5F). CaSki cell migration in the si-FEN1 and miR-140-5p mimic groups was significantly decreased by 40 and $50 \%$, respectively, but significantly increased in miR-140-5p inhibitor group by $70 \%$ compared with the blank group (Fig. 6F). However, cell migration in the co-transfection group was similar to the blank group.

\section{Discussion}

The present study identified a novel crosstalk between miR-140-5p and FEN1 in human CC. It was hypothesized that miR-140-5p displayed a CC-suppressing effect, whereas FEN1 displayed the opposite effect. The binding relationship between miR-140-5p and FEN1 predicted by TargetScan Human was also verified. The cell experiment results indicated that FEN1 knockdown inhibited CC cell proliferation, migration and uncontrollable cell cycle progression, whereas miR-140-5p 
A

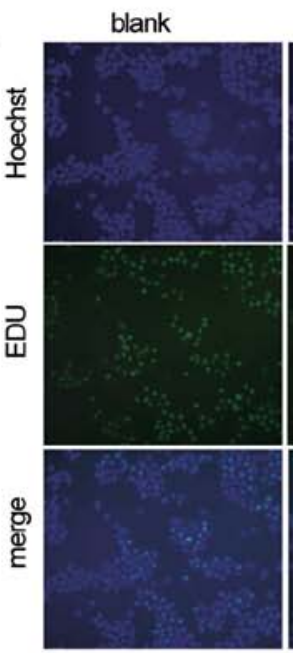

NC

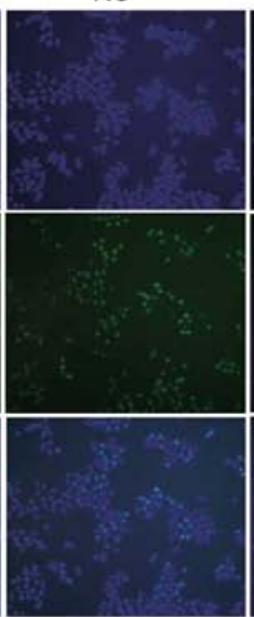

mimic
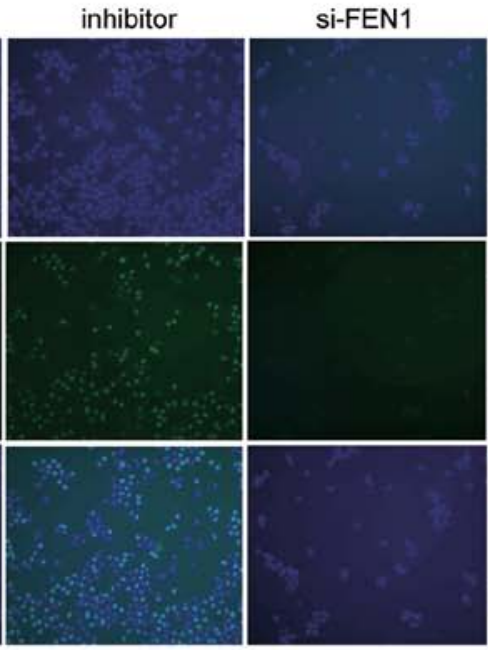

si-FEN1+inhibitor

B

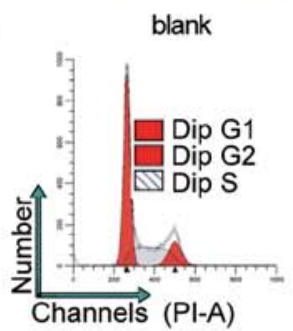

NC

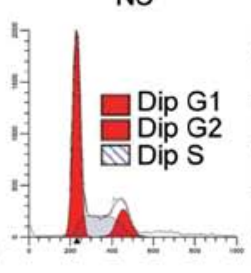

mimic

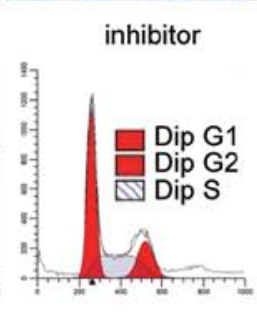

si-FEN1
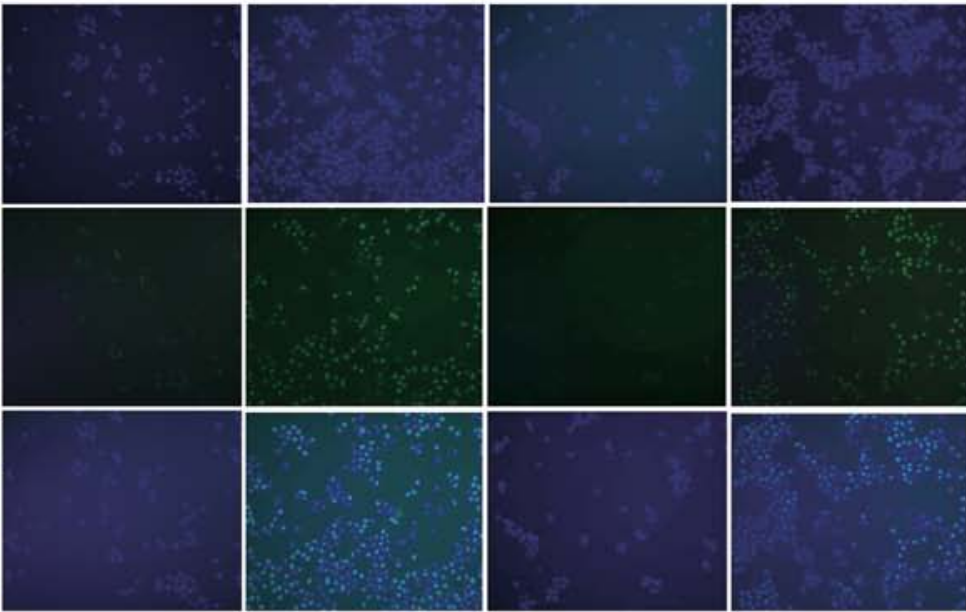

C
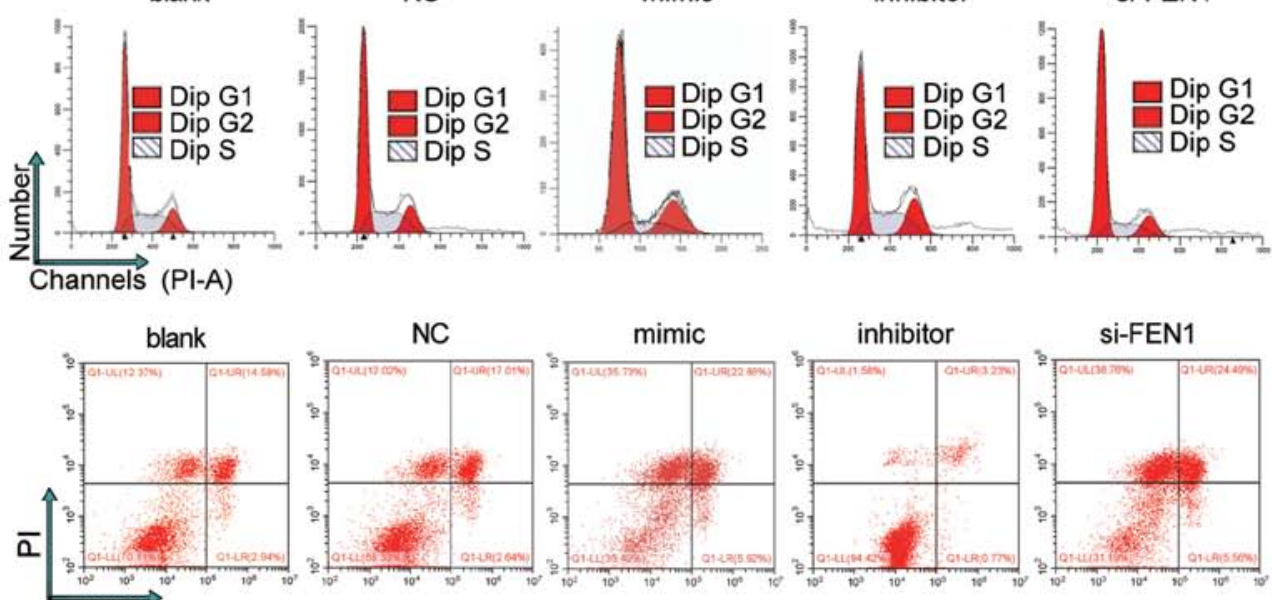

si-FEN1+inhibitor

$\overrightarrow{F I T C}$
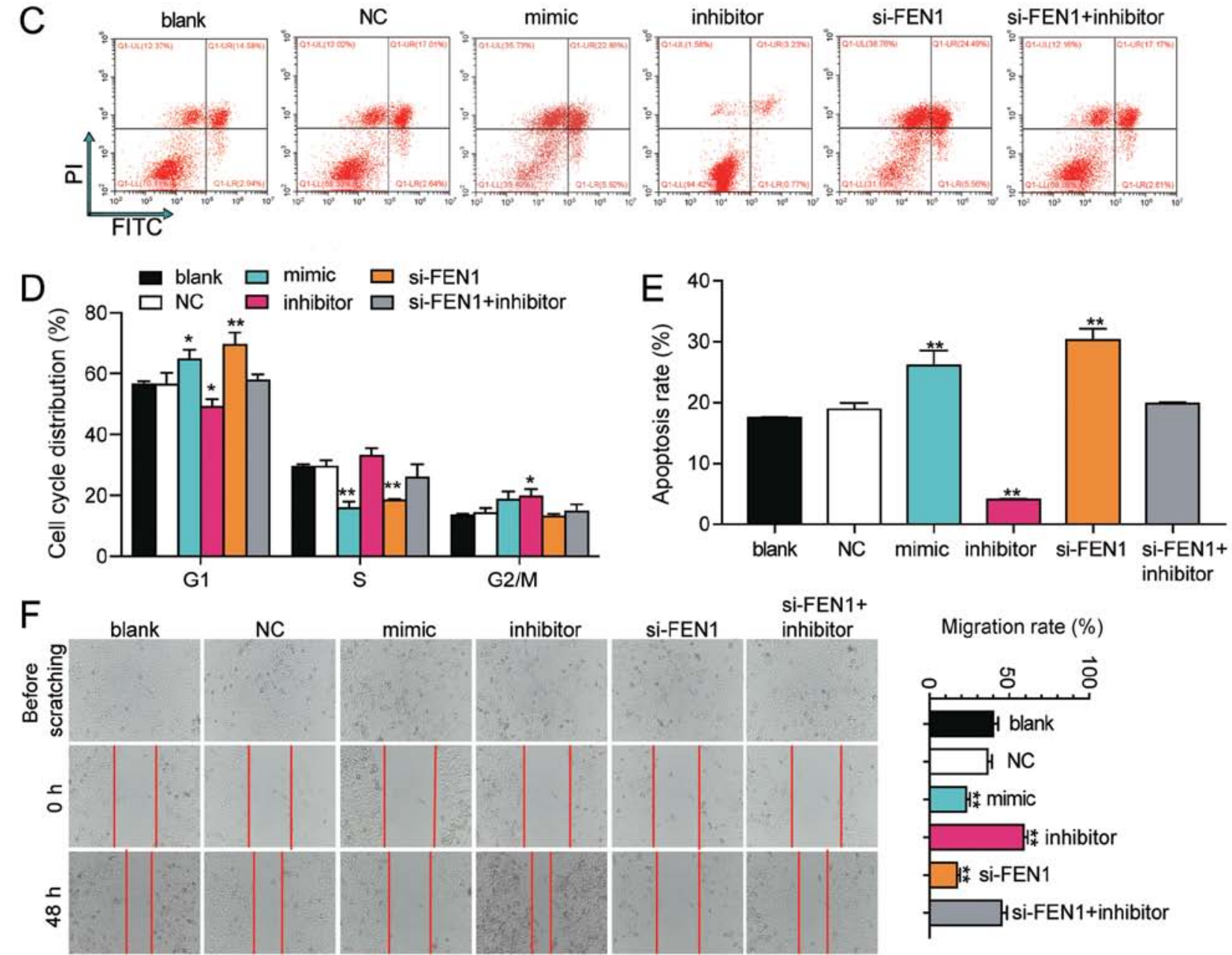

si-FEN1+inhibitor
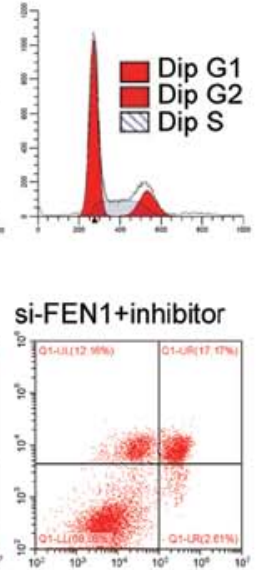

inhibitor

Figure 5. miR-140-5p inhibits cell proliferation and migration, and promotes cell apoptosis and cell cycle arrest at $\mathrm{G}_{1}$ phase by targeting FEN1 in the HeLa cell line. (A) Cell proliferation was detected by performing EdU staining (magnification, x100). (B) Flow cytometry was performed to assess the effects of miR-140-5p and FEN1 on (B) cell cycle distribution and (C) cell apoptosis. Quantification of (D) cell cycle distribution and (E) cell apoptosis. (F) The wound healing assay was conducted to assess the effects of miR-140-5p and FEN1 on cell migration (magnification, $\mathrm{x} 100$ ). ${ }^{*} \mathrm{P}<0.05$ and ${ }^{* * *} \mathrm{P}<0.001 \mathrm{vs}$. blank. miR, microRNA; FEN1, flap structure-specific endonuclease 1; NC, negative control; si, small interfering RNA. 

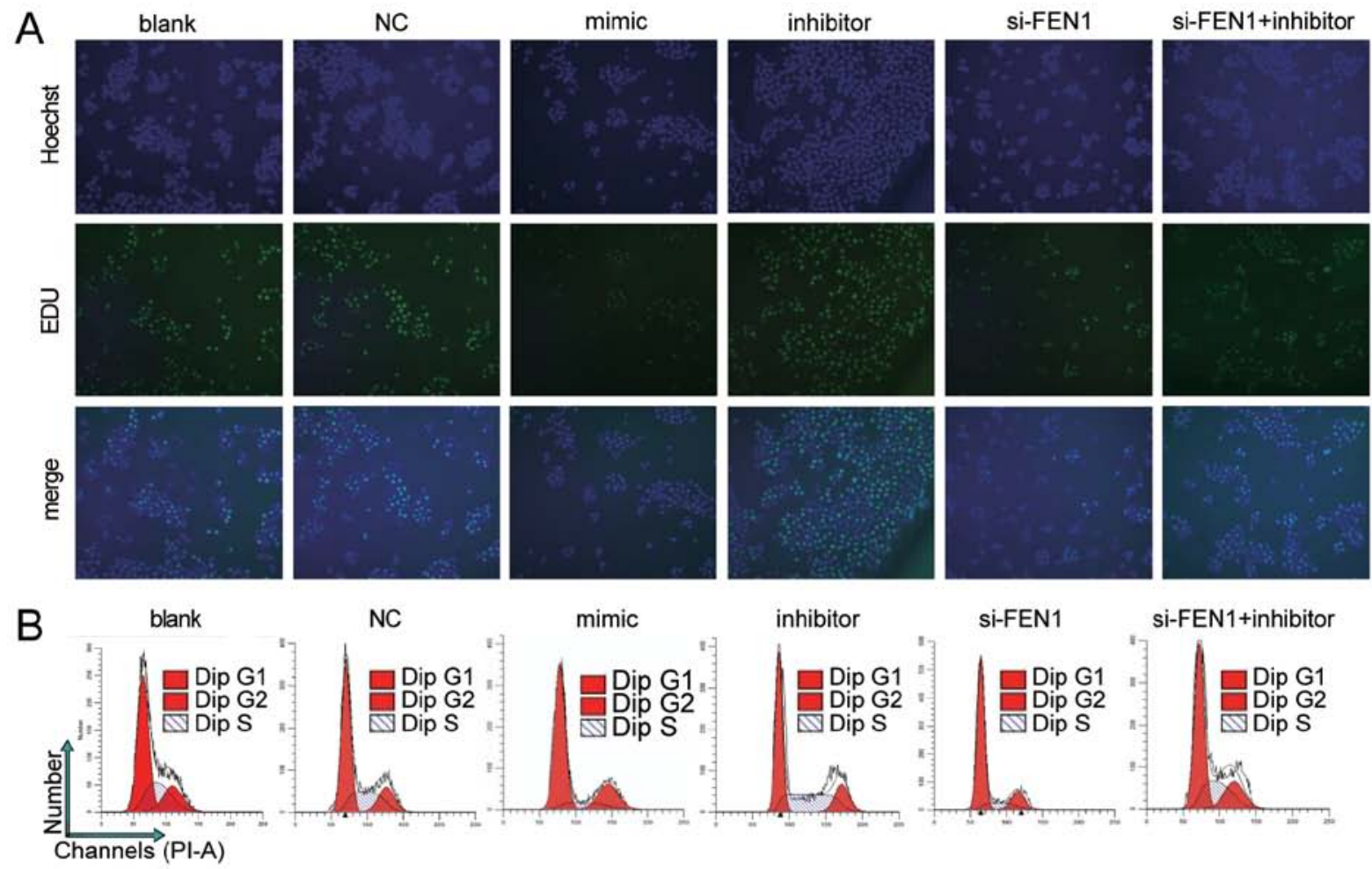

NC
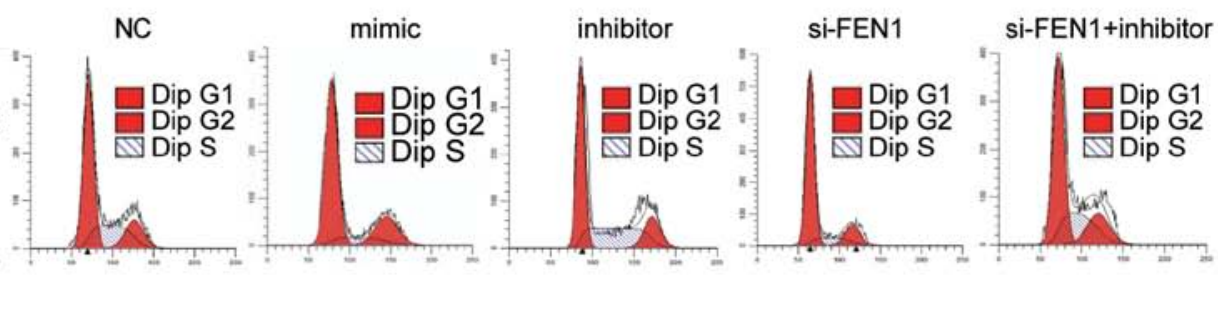

C
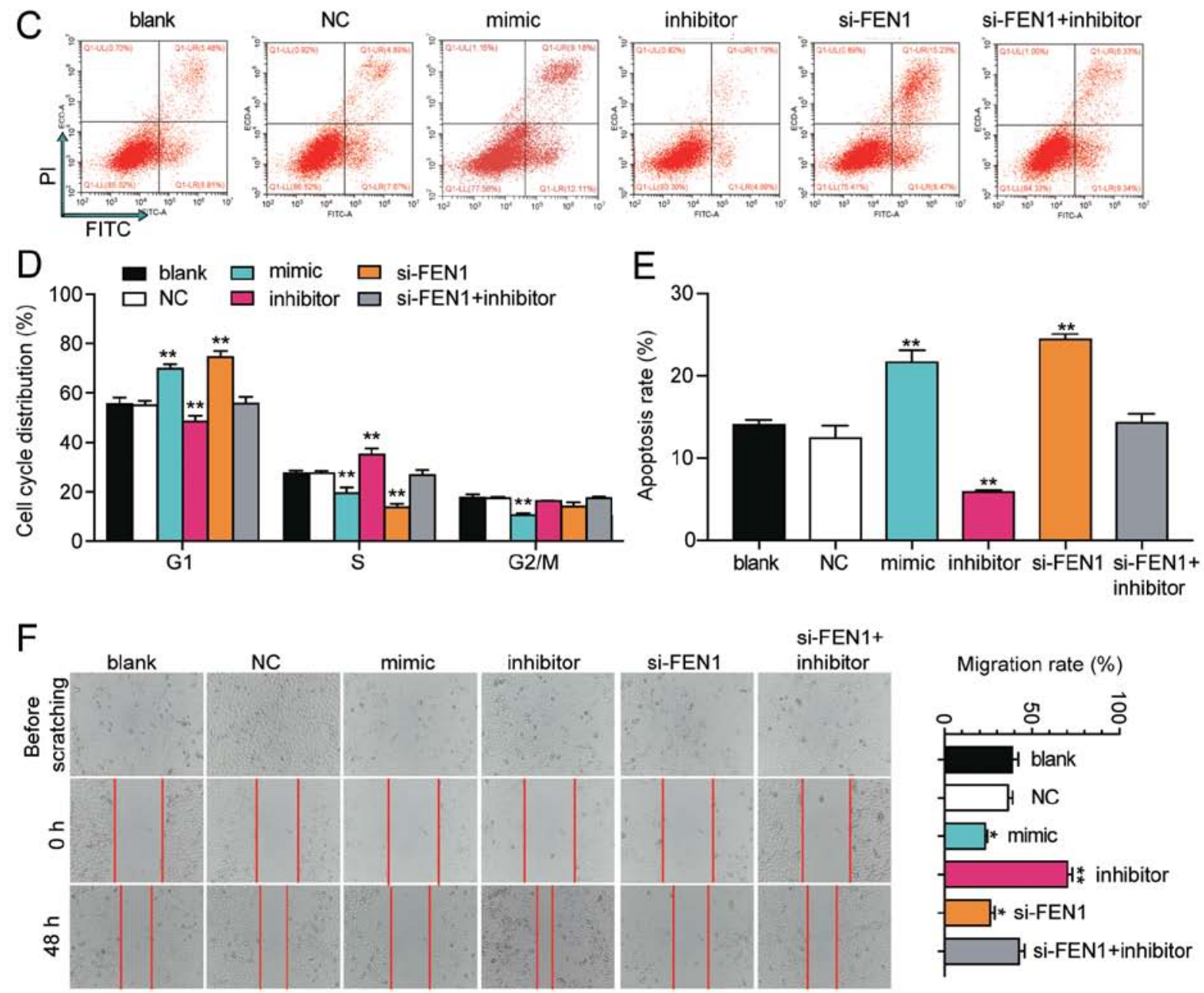

Figure 6. miR-140-5p inhibits cell proliferation and migration, and promotes cell apoptosis and cell cycle arrest at $\mathrm{G}_{1}$ phase by targeting FEN1 in the CaSki cell line. (A) Cell proliferation was detected by performing EdU staining (magnification, x100). (B) Flow cytometry was performed to assess the effects of miR-140-5p and FEN1 on (B) cell cycle distribution and (C) cell apoptosis. Quantification of (D) cell cycle distribution and (E) cell apoptosis. (F) The wound healing assay was conducted to assess the effects of miR-140-5p and FEN1 on cell migration (magnification, $\mathrm{x} 100$ ). " $\mathrm{P}<0.05$ and ${ }^{* * *} \mathrm{P}<0.001$ vs. blank. miR, microRNA; FEN1, flap structure-specific endonuclease 1; NC, negative control; si, small interfering RNA. 
inhibitor promoted CC cell proliferation, migration and cell cycle progression compared with the blank group.

To identify genes that potentially participated in the development of CC, three GEO datasets were analyzed in the present study. The bioinformatics analysis indicated that FEN1, in relation to the cell cycle, was a key gene that served an important role in CC. FEN1 is upregulated in various types of cancer, and FEN1 loss-of-function has been reported to inhibit cancer progression. For instance, He et al (26) reported that FEN1 was upregulated in lung cancer cells, and FEN1 inhibitor effectively inhibited cell proliferation and induced DNA damage in vitro. Also, FEN1 promoted breast cancer cell proliferation by mediating DNA methyltransferase (DNMT)1 and DNMT3a to recover the expression of miR-200a-5p target genes (31). In CC, FEN1 was upregulated in HeLa cells, and FEN1 loss-of-function resulted in significant DNA damage and CC cell proliferation (28). Besides, the combination of FEN1 inhibitor and ionizing radiation displayed an enhanced CC-suppressing effect (28). Another study demonstrated that the antitumor effect of paclitaxel was enhanced in CC cells when paclitaxel was used in combination with FEN1 inhibitor (53). Therefore, it was hypothesized that FEN1 might contribute to the development of $\mathrm{CC}$, and FEN1 knockdown might possess a CC-suppressing effect. The results of the present study indicated that FEN1 was significantly upregulated in CC tissues and cells compared with adjacent healthy tissues and HUCECs. FEN1 knockdown inhibited CC cell phenotypes compared with the blank group, including inhibiting cell mitosis by halting the cell cycle at the $\mathrm{G}_{1}$ phase. Similarly, Zhang et al (45) reported that FEN1 knockdown led to $G_{1} / S$ phase cell cycle arrest in lung cancer cells.

miRNAs have been regarded as negative regulators of target genes that also affect the progression of different types of cancer (54-56). miR-140-5p upregulation has been reported to impair the cancerous phenotypes of $\mathrm{CC}$ cells (41-43). miR-140-5p overexpression suppressed tumor growth and metastasis in nude mice (44). Interestingly, the effects of FEN1 and its regulator miR-140-5p in other types of cancer have been studied. For instance, overexpression of miR-140-5p and FEN1 in breast cancer resulted in reduced DNA damage and genome instability compared with miR-140-5p overexpression alone in breast cancer cell lines (29), suggesting that FEN1 rescued breast cancer cells from DNA damage and genome instability by compromising miR-140-5p. Similar results were observed in a hepatocellular carcinoma study, which reported that miR-140-5p and FEN1 overexpression reduced cell invasion and tumor growth (30). In the present study, the effects of si-FEN1 were blocked by miR-140-5p inhibitor, indicating a regulatory association between FEN1 and miR-140-5p. Compared with the blank group, miR-140-5p knockdown enhanced the malignant phenotypes of CC cell lines and FEN1 knockdown suppressed CC cell phenotypes. The results also indicated that miR-140-5p directly bound to FEN1 mRNA 3'UTR. Therefore, whether miR-140-5p inhibition could rescue FEN1 knockdown-induced phenotypes was investigated. The results indicated that the cancer-promoting effect of miR-140-5p inhibitor on CC was suppressed by si-FEN1. A potential explanation for the aforementioned effect is that the miR-140-5p inhibitor may have neutralized part of the endogenous miR-140-5p that bound to FEN1 mRNA 3'UTR, which freed some FEN1, compensating for the loss of FEN1 caused by si-FEN1 transfection.

Based on the results of the present study, it was hypothesized that miR-140-5p was an antitumor regulator in CC via suppressing FEN1 expression in vitro. However, whether miR-140-5p and FEN1 serve potential diagnostic and therapeutic benefits for patients with $\mathrm{CC}$ requires further investigation in vivo. In addition, whether the interaction between miR-140-5p and FEN1 exists in other CC cell lines should be investigated in future studies to generalize the axis to a wider range of $\mathrm{CC}$ cell lines. As a potential participant in the cell cycle signaling pathway, whether FEN1 could regulate the expression of certain cell cycle-related proteins and how FEN1 regulates cell cycle progression also require further investigation.

To the best of our knowledge, the present study suggested for the first time that miR-140-5p binding to FEN1 mRNA 3'UTR suppressed the cancerous phenotypes of HeLa and CaSki cell lines. Moreover, miR-140-5p knockdown prevented cell cycle arrest at the $\mathrm{G}_{1}$ phase by targeting FEN1 in HeLa and CaSki cell lines. Therefore, the present study provided insight into a potential therapeutic target for CC.

\section{Acknowledgements}

Not applicable.

\section{Funding}

No funding was received.

\section{Availability of data and materials}

The datasets used and/or analyzed during the current study are available from the corresponding author on reasonable request.

\section{Authors' contributions}

SL designed the study and prepared the manuscript. YG interpreted the data and supervised the experiments. SL and YG revised the manuscript. Both authors read and approved the final manuscript.

\section{Ethics approval and consent to participate}

The present study was approved by the Ethics Committee of Hanyang Hospital (approval no. AB-20.05/07) and The Second Affiliated Hospital of Nanchang University (approval no. NCEFY-04-23). All patients signed written informed consent.

\section{Patient consent for publication}

Not applicable.

\section{Competing interests}

The authors declare that they have no competing interests. 


\section{References}

1. Ding FN, Gao BH, Wu X, Gong CW, Wang WQ and Zhang SM miR-122-5p modulates the radiosensitivity of cervical cancer cells by regulating cell division cycle $25 \mathrm{~A}$ (CDC25A). FEBS Open Bio 9: 1869-1879, 2019.

2. Bao HL, Liu YN, Wang LJ, Fang LW, Cong S, Zhou MG and Wang LH: Analysis on mortality of cervical cancer and its temporal trend in women in China, 2006-2012. Zhonghua Liu Xing Bing Xue Za Zhi 38: 58-64, 2017 (In Chinese).

3. Cohen PA, Jhingran A, Oaknin A and Denny L: Cervical cancer. Lancet 393: 169-182, 2019.

4. Li H, Wu X and Cheng X: Advances in diagnosis and treatment of metastatic cervical cancer. J Gynecol Oncol 27: e43, 2016.

5. Menderes G, Black J, Schwab CL and Santin AD: Immunotherapy and targeted therapy for cervical cancer: An update. Expert Rev Anticancer Ther 16: 83-98, 2016.

6. Zhou Q, Dong J, Luo R, Zhou X, Wang J and Chen F: MicroRNA-20a regulates cell proliferation, apoptosis and autophagy by targeting thrombospondin 2 in cervical cancer. Eur J Pharmacol 844: 102-109, 2019.

7. Peng RQ, Wan HY, Li HF, Liu M, Li $X$ and Tang $H$ MicroRNA-214 suppresses growth and invasiveness of cervical cancer cells by targeting UDP-N-acetyl- $\alpha-\mathrm{D}$-galactosamine: Polypeptide N-acetylgalactosaminyltransferase 7. J Biol Chem 287: 14301-14309, 2012.

8. Ili CG, Brebi P, López J, García P, Leal P, Suarez E and Roa JC: Genotyping of human papillomavirus in cervical intraepithelial neoplasia in a high-risk population. J Med Virol 83: 833-837, 2011.

9. Cao XM: Role of miR-337-3p and its target Rap1A in modulating proliferation, invasion, migration and apoptosis of cervica cancer cells. Cancer Biomark 24: 257-267, 2019.

10. Cooper PR, Nowak NJ, Higgins MJ, Church DM and Shows TB Transcript mapping of the human chromosome 11q12-q13.1 gene-rich region identifies several newly described conserved genes. Genomics 49: 419-429, 1998.

11. Lieber MR: The FEN-1 family of structure-specific nucleases in eukaryotic DNA replication, recombination and repair. Bioessays 19: 233-240, 1997.

12. Henneke G, Friedrich-Heineken E and Hubscher U: Flap endonuclease 1: A novel tumour suppresser protein. Trends Biochem Sci 28: 384-390, 2003.

13. Kikuchi K, Taniguchi Y, Hatanaka A, Sonoda E, Hochegger H, Adachi N, Matsuzaki Y, Koyama H, van Gent DC, Jasin M and Takeda S: Fen-1 facilitates homologous recombination by removing divergent sequences at DNA break ends. Mol Cell Biol 25: 6948-6955, 2005.

14. Wu X, Wilson TE and Lieber MR: A role for FEN-1 in nonhomologous DNA end joining: The order of strand annealing and nucleolytic processing events. Proc Natl Acad Sci USA 96: 1303-1308, 1999.

15. Kucherlapati M, Yang K, Kuraguchi M, Zhao J, Lia M, Heyer J, Kane MF, Fan K, Russell R, Brown AM, et al: Haploinsufficiency of Flap endonuclease (Fen1) leads to rapid tumor progression. Proc Natl Acad Sci USA 99: 9924-9929, 2002.

16. Ayyagari R, Gomes XV, Gordenin DA and Burgers PM: Okazaki fragment maturation in yeast. I. Distribution of functions between FEN1 AND DNA2. J Biol Chem 278: 1618-1625, 2003.

17. Kim IS: Down-regulation of human FEN-1 gene expression during differentiation of promyelocytic leukemia cells. Exp Mol Med 30: 252-256, 1998.

18. Gary R, Park MS, Nolan JP, Cornelius HL, Kozyreva OG, Tran HT, Lobachev KS, Resnick MA and Gordenin DA: A novel role in DNA metabolism for the binding of Fen1/Rad27 to PCNA and implications for genetic risk. Mol Cell Biol 19: 5373-5382, 1999.

19. Warbrick E, Coates PJ and Hall PA: Fen1 expression: A novel marker for cell proliferation. J Pathol 186: 319-324, 1998.

20. Nikolova T, Christmann M and Kaina B: FEN1 is overexpressed in testis, lung and brain tumors. Anticancer Res 29: 2453-2459, 2009.

21. He L, Zhang Y, Sun H, Jiang F, Yang H, Wu H, Zhou T, Hu S, Kathera CS, Wang X, et al: Targeting DNA flap endonuclease 1 to impede breast cancer progression. EBioMedicine 14: 32-43, 2016.

22. Wang $\mathrm{K}$, Xie $\mathrm{C}$ and Chen D: Flap endonuclease 1 is a promising candidate biomarker in gastric cancer and is involved in cell proliferation and apoptosis. Int J Mol Med 33: 1268-1274, 2014.
23. Iacobuzio-Donahue CA, Maitra A, Olsen M, Lowe AW, van Heek NT, Rosty C, Walter K, Sato N, Parker A, Ashfaq R, et al: Exploration of global gene expression patterns in pancreatic adenocarcinoma using cDNA microarrays. Am J Pathol 162: 1151-1162, 2003.

24. Lam JS, Seligson DB, Yu H, Li A, Eeva M, Pantuck AJ, Zeng G, Horvath $S$ and Belldegrun AS: Flap endonuclease 1 is overexpressed in prostate cancer and is associated with a high Gleason score. BJU Int 98: 445-451, 2006.

25. Singh P, Yang M, Dai H, Yu D, Huang Q, Tan W, Kernstine KH, Lin D and Shen B: Overexpression and hypomethylation of flap endonuclease 1 gene in breast and other cancers. Mol Cancer Res 6: 1710-1717, 2008.

26. He L, Luo L, Zhu H, Yang H, Zhang Y, Wu H, Sun H, Jiang F, Kathera CS, Liu L, et al: FEN1 promotes tumor progression and confers cisplatin resistance in non-small-cell lung cancer. Mol Oncol 11: 640-654, 2017.

27. Zeng X, Che X, Liu YP, Qu XJ, Xu L, Zhao CY, Zheng CL, Hou KZ and Teng Y: FEN1 knockdown improves trastuzumab sensitivity in human epidermal growth factor 2-positive breast cancer cells. Exp Ther Med 14: 3265-3272, 2017.

28. Li JL, Wang JP, Chang H, Deng SM, Du JH, Wang XX, Hu HJ, Li DY, Xu XB, Guo WQ, et al: FEN1 inhibitor increases sensitivity of radiotherapy in cervical cancer cells. Cancer Med 8: 7774-7780, 2019

29. Lu X, Liu R, Wang M, Kumar AK, Pan F, He L, Hu Z and Guo Z: MicroRNA-140 impedes DNA repair by targeting FEN1 and enhances chemotherapeutic response in breast cancer. Oncogene 39: 234-247, 2020.

30. Li C, Zhou D, Hong H, Yang S, Zhang L, Li S, Hu P, Ren H, Mei Z and Tang H: TGF $\beta 1$-miR-140-5p axis mediated up-regulation of flap endonuclease 1 promotes epithelial-mesenchymal transition in hepatocellular carcinoma. Aging (Albany NY) 11: 5593-5612, 2019.

31. Zeng X, Qu X, Zhao C, Xu L, Hou K, Liu Y, Zhang N, Feng J, Shi S, Zhang L, et al: FEN1 mediates miR-200a methylation and promotes breast cancer cell growth via MET and EGFR signaling. FASEB J 33: 10717-10730, 2019.

32. Hammond SM: An overview of microRNAs. Adv Drug Deliv Rev 87: 3-14, 2015

33. Di Leva G, Garofalo M and Croce CM: MicroRNAs in cancer. Annu Rev Pathol 9: 287-314, 2014.

34. Li L, Song Y, Shi X, Liu J, Xiong S, Chen W, Fu Q, Huang Z, $\mathrm{Gu} \mathrm{N}$ and Zhang R: The landscape of miRNA editing in animals and its impact on miRNA biogenesis and targeting. Genome Res 28: 132-143, 2018.

35. Wang K, Jin W, Song Y and Fei X: LncRNA RP11-436H11.5, functioning as a competitive endogenous RNA, upregulates BCL-W expression by sponging miR-335-5p and promotes proliferation and invasion in renal cell carcinoma. Mol Cancer 16: 166, 2017.

36. Tuddenham L, Wheeler G, Ntounia-Fousara S, Waters J, Hajihosseini MK, Clark I and Dalmay T: The cartilage specific microRNA-140 targets histone deacetylase 4 in mouse cells. FEBS Lett 580: 4214-4217, 2006.

37. Shin VY, Ng EK, Chan VW, Kwong A and Chu KM: A three-miRNA signature as promising non-invasive diagnostic marker for gastric cancer. Mol Cancer 14: 202, 2015.

38. Zou J and Xu Y: MicroRNA-140 inhibits cell proliferation in gastric cancer cell line HGC-27 by suppressing SOX4. Med Sci Monit 22: 2243-2252, 2016

39. Yang H, Fang F, Chang R and Yang L: MicroRNA-140-5p suppresses tumor growth and metastasis by targeting transforming growth factor $\beta$ receptor 1 and fibroblast growth factor 9 in hepatocellular carcinoma. Hepatology 58: 205-217, 2013.

40. Li W, Jiang G, Zhou J, Wang H, Gong Z, Zhang Z, Min K, Zhu H and Tan Y: Down-regulation of miR-140 induces EMT and promotes invasion by targeting Slug in esophageal cancer. Cell Physiol Biochem 34: 1466-1476, 2014.

41. Guo H, Yang S, Li S, Yan M, Li L and Zhang H: LncRNA SNHG20 promotes cell proliferation and invasion via miR-140-5p-ADAM10 axis in cervical cancer. Biomed Pharmacother 102: 749-757, 2018.

42. Chen X, Xiong D, Ye L, Wang K, Huang L, Mei S, Wu J, Chen S, Lai X, Zheng L and Wang M: Up-regulated lncRNA XIST contributes to progression of cervical cancer via regulating miR-140-5p and ORC1. Cancer Cell Int 19: 45, 2019.

43. Chang QQ, Chen CY, Chen Z and Chang S: LncRNA PVT1 promotes proliferation and invasion through enhancing Smad3 expression by sponging miR-140-5p in cervical cancer. Radiol Oncol 53: 443-452, 2019. 
44. Su Y,Xiong J,Hu J, Wei X,Zhang X and Rao L: MicroRNA-140-5p targets insulin like growth factor 2 mRNA binding protein 1 (IGF2BP1) to suppress cervical cancer growth and metastasis. Oncotarget 7: 68397-68411, 2016.

45. Zhang K, Keymeulen S, Nelson R, et al: Overexpression of Flap endonuclease 1 correlates with enhanced proliferation and poor prognosis of non-small-cell lung cancer. Am J Pathol 188 242-251, 2018.

46. Pappa KI, Polyzos A, Jacob-Hirsch J, Amariglio N, Vlachos GD, Loutradis D and Anagnou NP: Profiling of discrete gynecological cancers reveals novel transcriptional modules and common features shared by other cancer types and embryonic stem cells. PLoS One 10: e0142229, 2015.

47. Li JH, Liu S, Zhou H, Qu LH and Yang JH: starBase v2.0: Decoding miRNA-ceRNA, miRNA-ncRNA and protein-RNA interaction networks from large-scale CLIP-Seq data. Nucleic Acids Res 42 (Database Issue): D92-D97, 2014.

48. Livak KJ and Schmittgen TD: Analysis of relative gene expression data using real-time quantitative PCR and the 2(-Delta Delta C(T)) method. Methods 25: 402-408, 2001.

49. Salim H, Akbar NS, Zong D, Vaculova AH, Lewensohn R, Moshfegh A, Viktorsson K and Zhivotovsky B: miRNA-214 modulates radiotherapy response of non-small cell lung cancer cells through regulation of $\mathrm{p} 38 \mathrm{MAPK}$, apoptosis and senescence. Br J Cancer 107: 1361-1373, 2012.

50. Zhang K, Keymeulen S, Nelson R, Tong TR, Yuan YC, Yun X, Liu Z, Lopez J, Raz DJ and Kim JY: Overexpression of flap endonuclease 1 correlates with enhanced proliferation and poor prognosis of non-small-cell lung cancer. Am J Pathol 188: 242-251, 2018
51. He L, Luo L, Zhu H, Yang H, Zhang Y, Wu H, Sun H, Jiang F, Kathera CS, Liu L, et al: FEN1 promotes tumor progression and confers cisplatin resistance in non-small-cell lung cancer. Mol Oncol 11: 1302-1303, 2017.

52. Zhang Y, Liu X, Liu L, Chen J, Hu Q, Shen S, Zhou Y, Chen S, Xue C, Cui G and Yu Z: Upregulation of FEN1 is associated with the tumor progression and prognosis of hepatocellular carcinoma. Dis Markers 2020: 2514090, 2020.

53. He L, Yang H, Zhou S, Zhu H, Mao H, Ma Z, Wu T, Kumar AK, Kathera C, Janardhan A, et al: Synergistic antitumor effect of combined paclitaxel with FEN1 inhibitor in cervical cancer cells. DNA Repair (Amst) 63: 1-9, 2018.

54. Minna E, Romeo P, Dugo M, De Cecco L, Todoerti K, Pilotti S, Perrone F, Seregni E, Agnelli L, Neri A, et al: miR-451a is underexpressed and targets AKT/mTOR pathwayinpapillarythyroidcarcinoma. Oncotarget 7: 12731-12747, 2016.

55. Liu H, Ren G, Zhu L, Liu X and He X: The upregulation of miRNA-146a inhibited biological behaviors of ESCC through inhibition of IRS2. Tumour Biol 37: 4641-4647, 2016.

56. Li X, Zhang Y, Zhang H, Liu X, Gong T, Li M, Sun L, Ji G, Shi Y, Han Z, et al: miRNA-223 promotes gastric cancer invasion and metastasis by targeting tumor suppressor EPB41L3. Mol Cancer Res 9: 824-833, 2011. 